\title{
Taxonomic notes on two jumping spider species of the genus Epocilla Thorell, 1887 (Araneae: Salticidae: Chrysillini) from India and Pakistan
}

\author{
Таксономические заметки о двух видах пауков-скакунчиков \\ рода Epocilla Thorell, 1887 (Araneae: Salticidae: Chrysillini) \\ из Индии и Пакистана
}

\author{
John T.D. Caleb ${ }^{1^{*}}$, Rajesh V. Sanap ${ }^{2}$, Dhruv A. Prajapati ${ }^{3}$, \\ Prakash Bambhaniya ${ }^{4}$ \\ Ажкон Т.А. Калеб ${ }^{*}$, Раджеш В. Санап², Ахрув А. Праджапати \\ Пракаш Бамбханья ${ }^{4}$
}

\footnotetext{
${ }^{1}$ Zoological Survey of India, Prani Vigyan Bhawan, M-Block, New Alipore, Kolkata - 700 053, West Bengal, India.

2 Biodiversity Lab, National Centre for Biological Sciences, Tata Institute of Fundamental Research, GKVK Campus, Bellary Road, Bengaluru - 560 065, Karnataka, India.

${ }^{3}$ GEER Foundation, Indroda Nature Park, Gandhinagar - 382 007, Gujarat, India.

${ }^{4}$ Fisheries Research Station, Junagadh Agricultural University, Sikka, Jamnagar - 361 140, Gujarat, India.

*Corresponding author: caleb87woodgate@gmail.com
}

KEY WORDS: Andaman Islands, Aranei, distribution, faunistic records, map, synonymy, types.

КЛЮЧЕВЫЕ СЛОВА: Андаманские острова, Aranei, распространение, фаунистические находки, карта, синонимия, типы.

ABSTRACT. The types of Marpissa tigrina Tikader, 1965 and M. kalapani Tikader, 1977 that are kept in the National Zoological collection, Zoological Survey of India (Kolkata) are re-examined and illustrated. A new combination, Epocilla aura (Dyal, 1935) comb.n. (ex. Thiania), is proposed and three new synonyms are established: Epocilla pakhtunkhwa Ali et Maddison, 2018 syn.n. and Marpissa tigrina Tikader, 1965 syn.n. with E. aura, and Marpissa kalapani Tikader, 1977 syn.n. with Epocilla calcarata (Karsch, 1880). The distributional records of these species from India and Pakistan are mapped.

How to cite this paper: Caleb J.T.D., Sanap R.V., Prajapati D.A., Bambhaniya P. 2021. Taxonomic notes on two jumping spider species of the genus Epocilla Thorell, 1887 (Araneae: Salticidae: Chrysillini) from India and Pakistan // Arthropoda Selecta. Vol.30. No.2. P.221-229. doi: 10.15298/arthsel.30.2.09

РЕЗЮМЕ. Изучены и иллюстрированы типы Marpissa tigrina Tikader, 1965 и M. kalapani Tikader, 1977 из Национальной Зоологической коллекции, Зоологическая Служба Индии (Калькутта). Предложена новая комбинация, Epocilla aura (Dyal, 1935) comb.n. (ех. Thiania), и установлены три новых синонима: Epocilla pakhtunkhwa Ali et Maddison, 2018 syn.n. и Marpissa tigrina Tikader, 1965 syn.n. с E. aura, и Marpissa kalapani Tikader, 1977 syn.n. с
Epocilla calcarata (Karsch, 1880). Точки находок этих видов в Индии и Пакистане прокартированы.

\section{Introduction}

The Oriental jumping spider genus Epocilla was erected by Thorell [1887], with Epocilla praetextata Thorell, 1887 as its generotype. It currently includes twelve species from the Oriental Region [WSC, 2021], of which four are known from India $-E$. aurantiaca (Simon, 1885), E. praetextata Thorell, 1887, E. sirohi Caleb, Chatterjee, Tyagi, Kundu et Kumar, 2017 and E. xylina Simon, 1906 - and one from Pakistan: E. pakhtunkhwa Ali et Maddison, 2018 [Caleb, Sankaran, 2021; WSC, 2021]. All Indian species of Marpissa C.L. Koch, 1846 are misplaced, with some of them having been recently re-examined and their taxonomic status revised [Caleb et al., 2017, 2019, 2020]. While identifying samples from India and Pakistan, we have compared our specimens with the descriptions and illustrations of Salticidae by Dyal [1935] and found out that the description of Thiania aura Dyal, 1935 matches perfectly that of Marpissa tigrina Tikader, 1965.

In the present paper, we aim (1) to provide a taxonomic note on Marpissa kalapani Tikader 1977, (2) to redescribe Thiania aura Dyal, 1935 based on newly collected specimens from several localities in India 

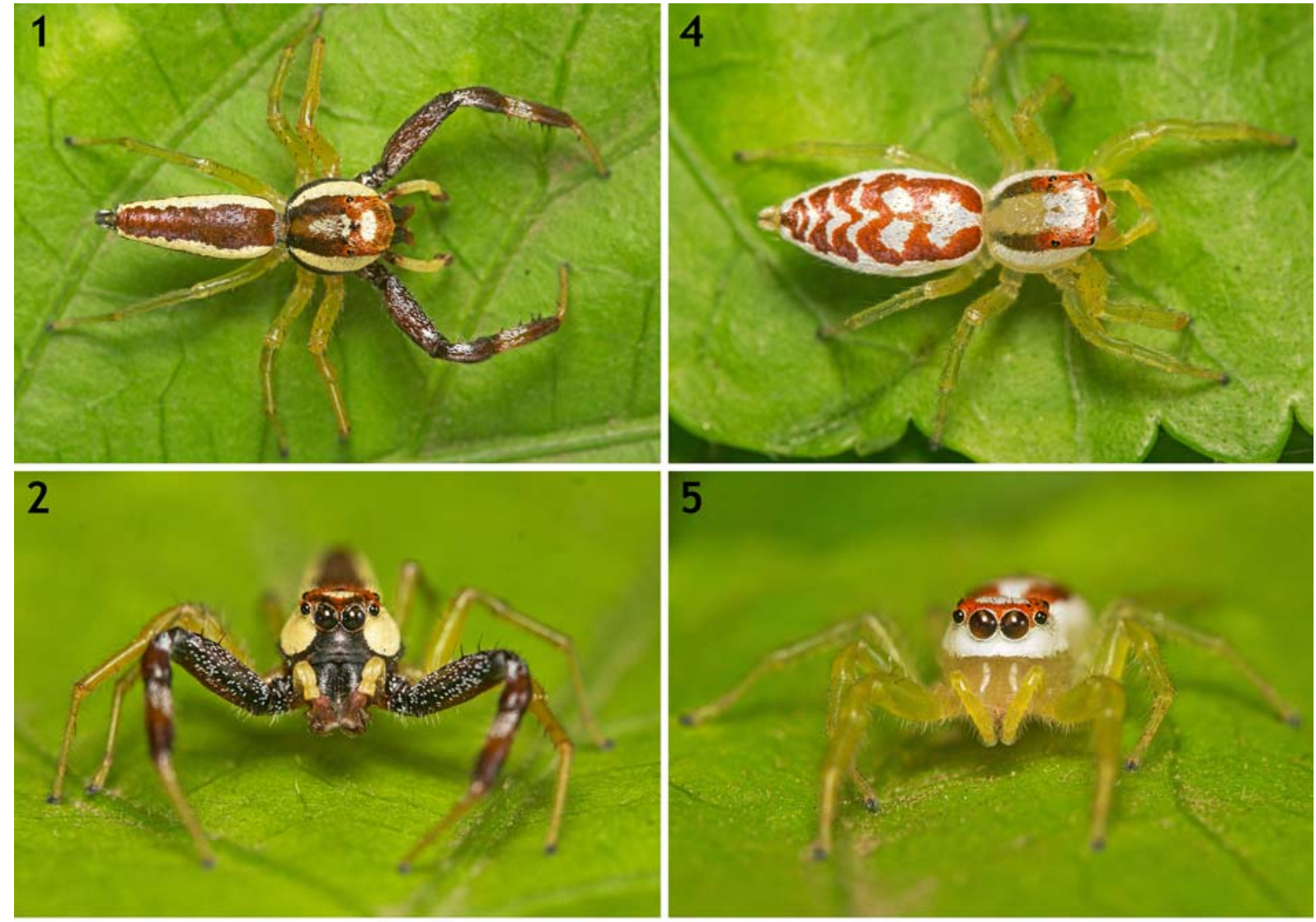

3

6
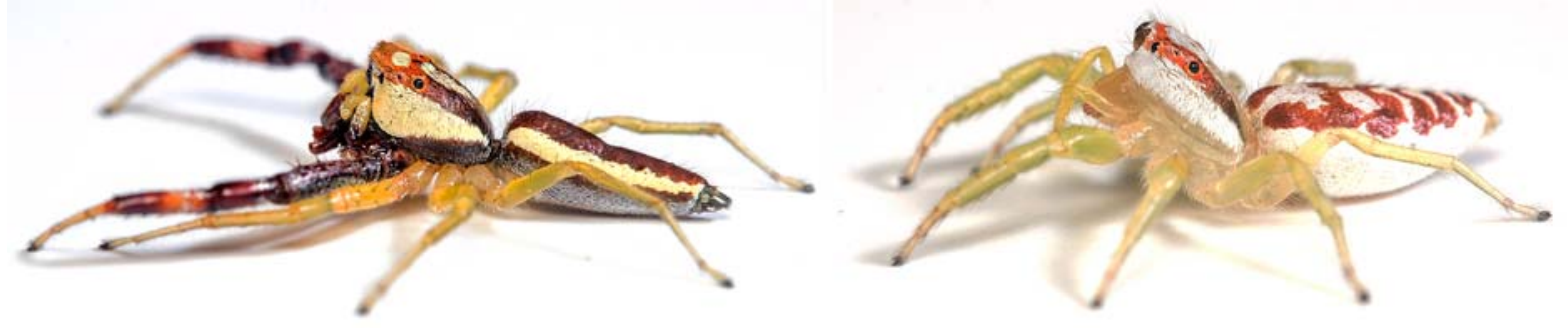

Figs 1-6. Epocilla aura (Dyal, 1935) comb.n., live specimens from Nashik, Maharashtra: 1 - male, dorsal view; 2 - ditto, front view; 3 - ditto, lateral view; 4 - female, dorsal view; 5 - ditto, front view; 6 - ditto, lateral view.

Pис. 1-6. Epocilla aura (Dyal, 1935) comb.n., живые экземпляры из Нашик, Махараштра: 1 - самец, вид сверху; 2 - то же, вид спереди; 3 - то же, вид сбоку; 4 - самка, вид сверху; 5 - то же, вид спереди; 6 - то же, вид сбоку.

and Pakistan, and (3) to justify the synonymy of three species names.

\section{Materials and methods}

Live specimens were photographed using a Canon DSLR 60D, 60mm lens with Canon Speedlite 430 EX II, Canon Speedlite 600 EX-RT or Macro ring lite YN14EX external flash. Specimens were preserved in $70 \%$ alcohol and later examined under a Leica EZ4 HD stereoscopic microscope. The type specimens at the National Zoological collection, Zoological Survey of India (Kolkata) were examined and imaged using a Leica EZ4 HD stereomicroscope equipped with LAS EZ software. Detailed micro-photographs were obtained using Leica M205 A stereomicroscope with a Leica
DFC500 HD camera attached to it that is enabled with a Leica Application Suite (LAS) version 3.8. Male palps were detached and studied in detail. Female copulatory organs were excised using fine surgical blade and macerated in 10\% $\mathrm{KOH}$. The description format and style follow Caleb et al. [2017]. All measurements are in $\mathrm{mm}$.

Abbreviations used in the text are as follows: AER anterior eye row; ALE \& A.L. - anterior lateral eye; AME anterior median eye; PLE - posterior lateral eye; PME posterior median eye.

The specimens are deposited in the following museum and private collections: GEER - Gujarat Ecological and Educational Research Foundation, Gandhinagar, Gujarat, India (curator: Dhruv A. Prajapati); MMUE - Manchester Museum, University of Manchester, Oxford Rd, Manchester, UK (curator: Dmitri V. Logunov); NZC-ZSIK — Na- 

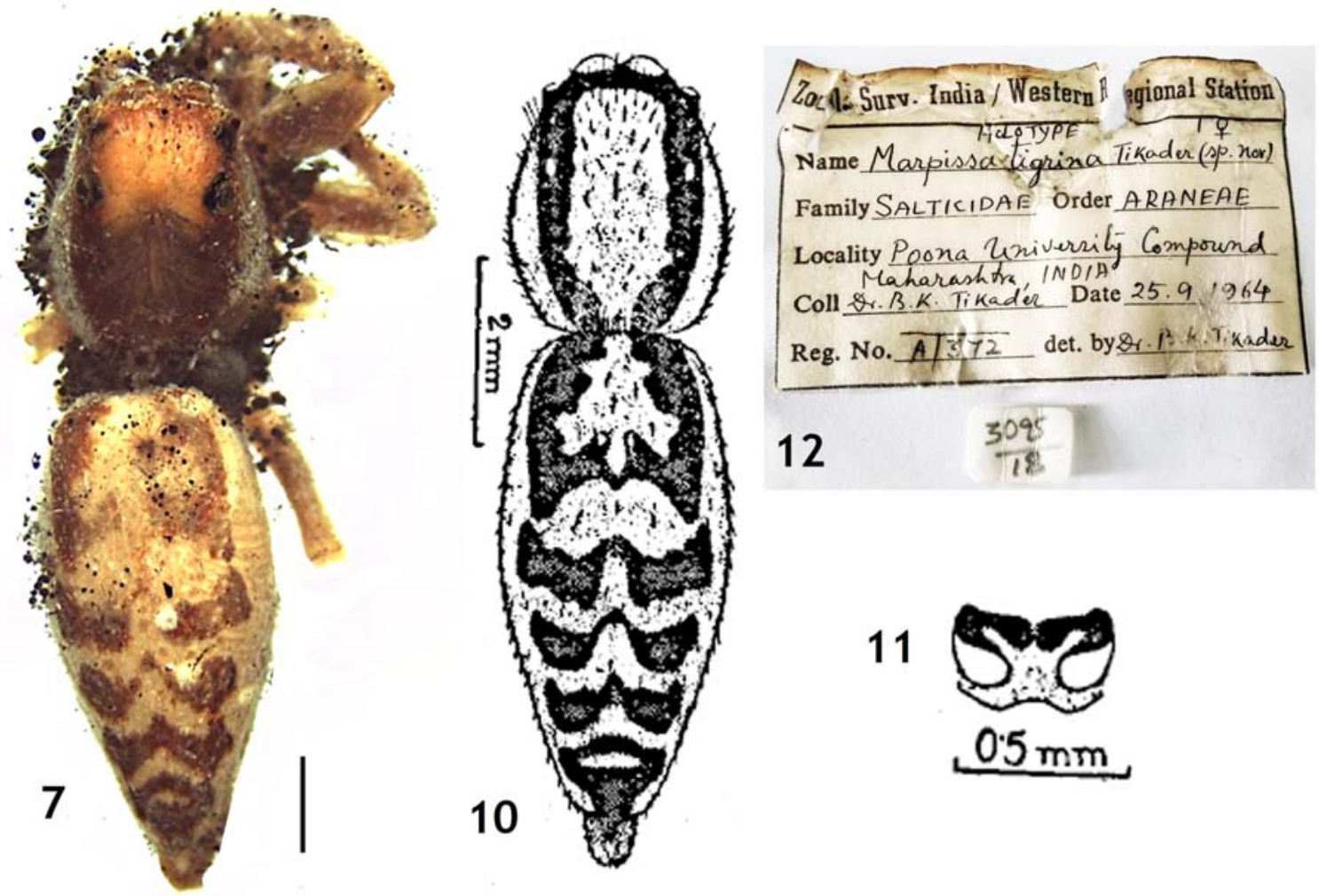

8

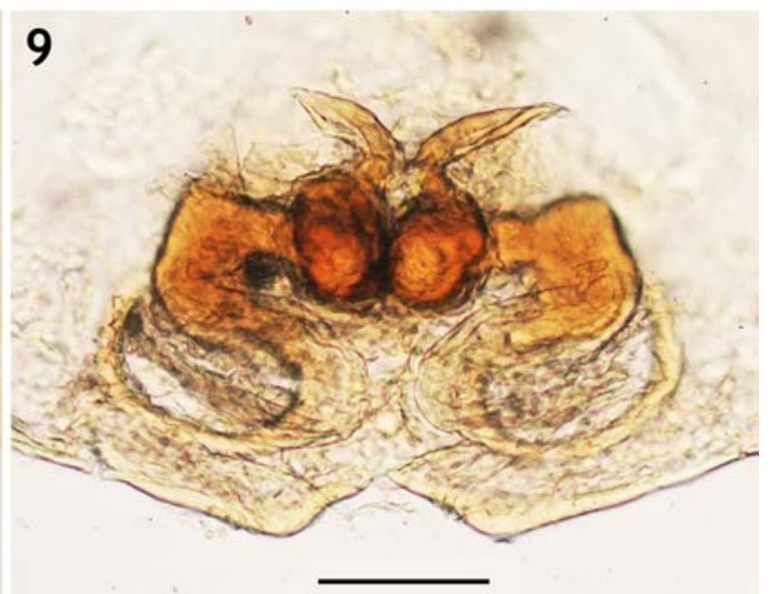

Figs 7-12. Epocilla aura (Dyal, 1935) comb.n., general appearance and copulatory organs of the holotype female $(7,10,11)$ and paratype female $(8,9)$ of Marpissa tigrina Tikader, 1965, syn.n.: 7, 10 - body, dorsal view; 8, 11 - epigyne, ventral view; 9 spermathecae, dorsal view; 12 - type data label. Figs $10 \& 11$ adopted from Tikader [1965]. Scale bars: (10) $2 \mathrm{~mm}$; (7) $1 \mathrm{~mm}$; (11) 0.5 $\mathrm{mm}$; (8) $0.2 \mathrm{~mm}$; (9) $0.1 \mathrm{~mm}$.

Рис. 7-12. Epocilla aura (Dyal, 1935) comb.n., общий вид и копулятивные органы самки-голотипа $(7,10,11)$ и самки-паратипа $(8,9)$ Marpissa tigrina Tikader, 1965, syn.n.: 7, 10 - тело, вид сверху; 8, 11 - эпигина, вид снизу; 9 - сперматека, вид сверху; 12 этикетка типа. Рис. 10 \& 11 взяты из Tikader [1965]. Масштаб: (10) 2 мм; (7) 1 мм; (11) 0,5 мм; (8) 0,2 мм; (9) 0,1 мм.

tional Zoological Collections, Arachnida Section, Zoological Survey of India, Kolkata (curator: Shelley Acharya); RVSC - personal collection of Rajesh V. Sanap (Mumbai, Maharashtra, India).

\section{Taxonomy}

\section{Epocilla Thorell, 1887}

Type species: Epocilla praetextata Thorell, 1887; by monotypy.

\section{Epocilla aura (Dyal, 1935) comb.n.}

Figs 1-29, Map.

Thiania aura Dyal, 1935: 230, pl. 17, fig. 177 (Do' 9$)$; type depository unknown, not examined.

Marpissa tigrina Tikader, 1965: 261, figs 1a-b (D+); holotype 9 in ZSIK, examined, syn.n.

Marpissa tigrina: Tikader, Biswas, 1981: 97, figs 177-178.

Epocilla pakhtunkhwa Ali et Maddison, in Ali et al., 2018: 4, figs 1-4 (D $\left.{ }^{7}\right)$; holotype $O^{7}$ in the Spencer Entomological Collection, University of British Columbia, Canada, not examined, syn.n. 


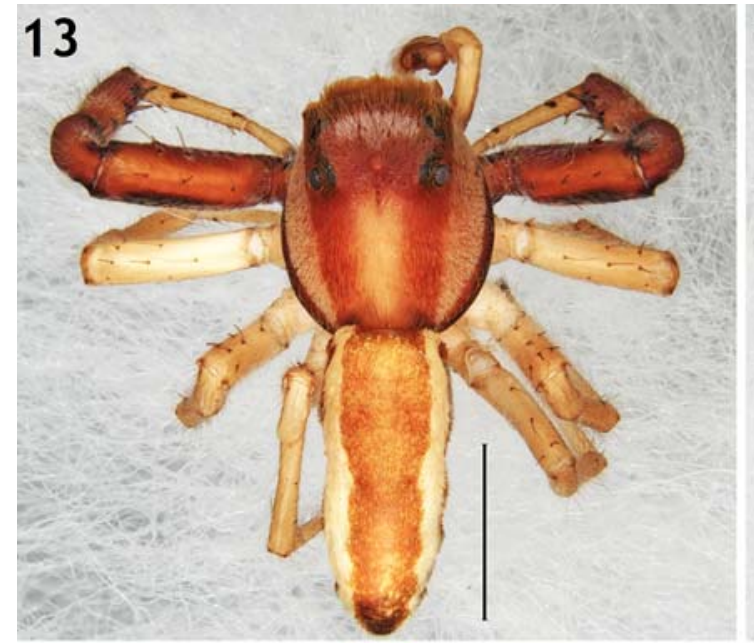

15

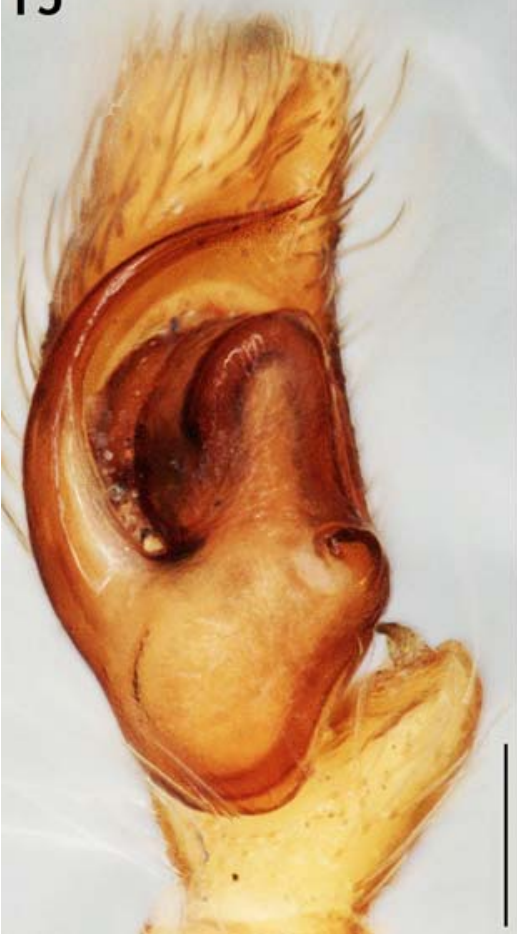

16

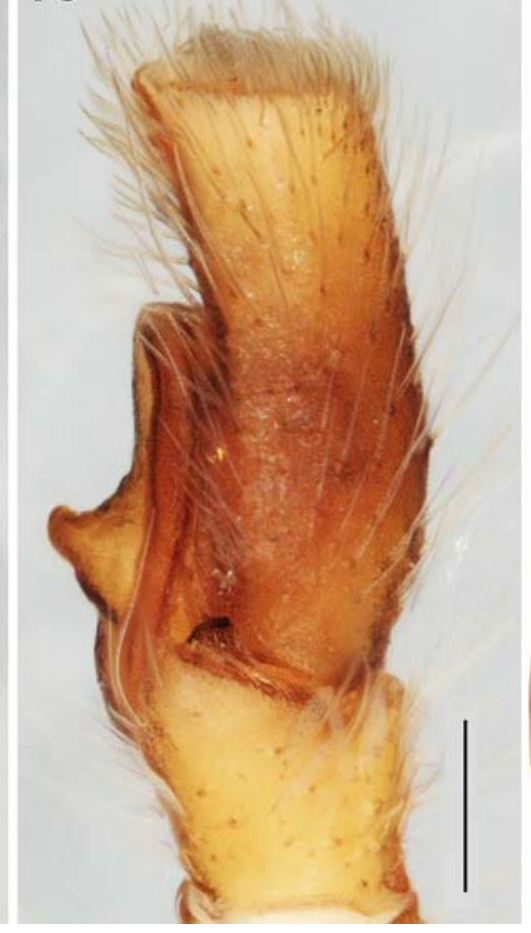

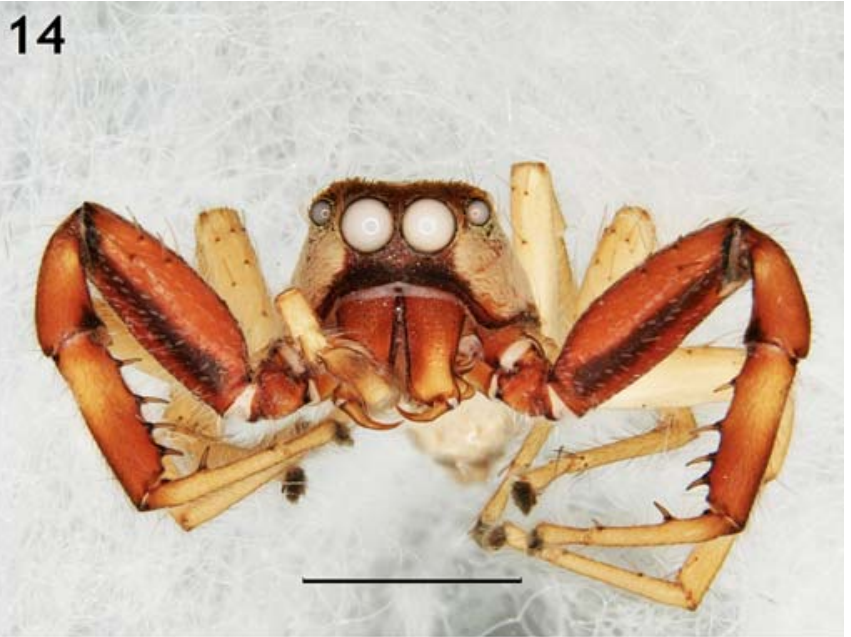

17

Figs 13-17. Epocilla aura (Dyal, 1935) comb.n., general appearance and copulatory organs of the male from Maharashtra: 13 body, dorsal view; 14 - carapace, front view; 15 - left palp, ventral view; 16 - ditto, retrolateral view; 17 - embolus, ventro-lateral view. Scale bars: $(13,14) 2 \mathrm{~mm}$; (15-16) $0.2 \mathrm{~mm}$; (17) $0.1 \mathrm{~mm}$.

Рис. 13-17. Epocilla aura (Dyal, 1935) comb.n., общий вид и копулятивные органы самца из Махараштры: 13 - тело, вид сверху; 14 - головогрудь, вид спереди; 15 - левая пальпа, вид снизу; 16 - то же, вид сбоку-сзади; 17 - эмболюс, вид снизусбоку. Масштаб: $(13,14) 2$ мм; (15-16) 0,2 мм; (17) 0,1 мм.

TYPES. Marpissa tigrina Tikader, 1965: HolotyPe 9 (NZCZSIK, 3095/18) from India, Maharashtra, Pune (=Poona), Poona University compound $\left(18^{\circ} 33^{\prime} 08.3^{\prime \prime} \mathrm{N}, 73^{\circ} 49^{\prime} 37.9^{\prime \prime} \mathrm{E}\right), 580 \mathrm{~m}$ a.s.1. 25.09.1964, B.K. Tikader. PARATYPES: 4 +o (NZC-ZSIK, 3100/18), together with the holotype (all in poor condition, dried up and moulded; see Fig. 7).

OTHER MATERIAL. INDIA: 1 (NZC-ZSIK, 6442/18), West Bengal, Kolkata, New Alipore Railway Station $\left(22^{\circ} 30^{\prime} 34.6^{\prime \prime} \mathrm{N}\right.$ $\left.88^{\circ} 20^{\prime} 08.5^{\prime \prime} \mathrm{E}\right), 9 \mathrm{~m}$ a.s.1., 17.02.2018, C. Bera; $1 \mathrm{O}^{\top}, 1$ q (RVSC) from Sinnar, Nashik $\left(19^{\circ} 56^{\prime} 14.70^{\prime \prime} \mathrm{N}, 74^{\circ} 6^{\prime} 19.23^{\prime \prime} \mathrm{E}\right), 574 \mathrm{~m}$ a.s.l., 24.09.2019, R.V. Sanap; $1 \sigma^{\top}, 1$ क (RVSC) from Aarey Milk Colony $\left(19^{\circ} 8^{\prime} 33.34^{\prime \prime} \mathrm{N}, 72^{\circ} 52^{\prime} 2.88^{\prime \prime} \mathrm{E}\right), 37 \mathrm{~m}$ a.s.1. + - 27.08.2017
$\& \sigma^{7}-1.04 .2017$, R.V. Sanap; 1 ( 9 (GEER, 9742A), Gujarat, Ahmadabad, Gujarat University campus, $\left(23^{\circ} 02^{\prime} 15.66^{\prime \prime} \mathrm{N}, 72^{\circ} 32^{\prime}\right.$ $35.24^{\prime \prime} \mathrm{E}$ ), $53 \mathrm{~m}$ a.s.1., hand-collected from foliage, 15.02.2015, D.A. Prajapati; 1 ণ , 1 (GEER, 9743A), Gujarat, Jamnagar, Sikka $\left(22^{\circ} 26^{\prime} 22.0^{\prime \prime} \mathrm{N}, 69^{\circ} 50^{\prime} 08.2^{\prime \prime} \mathrm{E}\right), 5 \mathrm{~m}$ a.s.1., from foliage, 2.09. 2020, P. Bambhaniya. - PAKISTAN: 1 ( (MMUE), Lahore, jasmine and Plumeria leaves, 16.05.2013, G. Rasool; $1 \sigma^{7}$ (MMUE), same locality, 2013, G. Rasool.

DIAGNOSIS. In having a longer embolus, the male is similar to those of E. aurantiaca, E. blairei Żabka, 1985 and E. sirohi but can be distinguished by the expanded flange at the tip of the embolus and the narrower and deeper cleft 


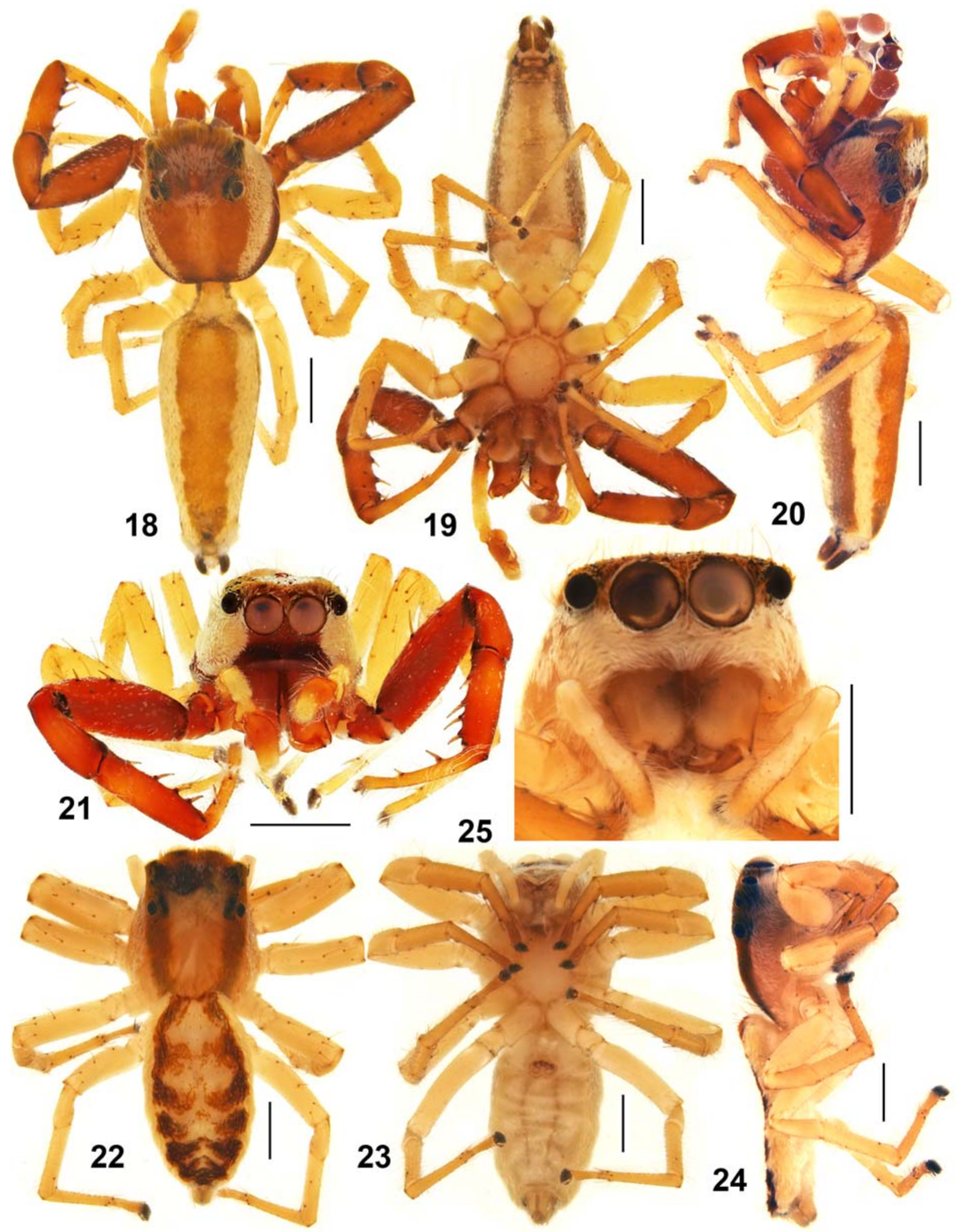

Figs 18-25. Epocilla aura (Dyal, 1935) comb.n., general appearance of the topotypes from Lahore, Pakistan: 18 - male body, dorsal view; 19 - ditto, ventral view; 20 - ditto, lateral view; 21 - carapace, front view; 22 - female body, dorsal view; 23 - ditto, ventral view; 24 - ditto, lateral view; 25 - carapace, front view. Scale bars: $1 \mathrm{~mm}$. Images kindly provided by D.V. Logunov.

Рис. 18-25. Epocilla aura (Dyal, 1935) comb.n., общий вид топотипов из Лахора, Пакистан: 18 - тело самца, вид сверху; $19-$ то же, вид снизу; 20 - то же, вид сбоку; 21 — головогрудь, вид спереди; 22 - тело самки, вид сверху; 23 — то же, вид снизу; 24 то же, вид сбоку; 25 - головогрудь, вид спереди. Масштаб: 1 мм. Изображения любезно предосталены Д.В. Логуновым. 

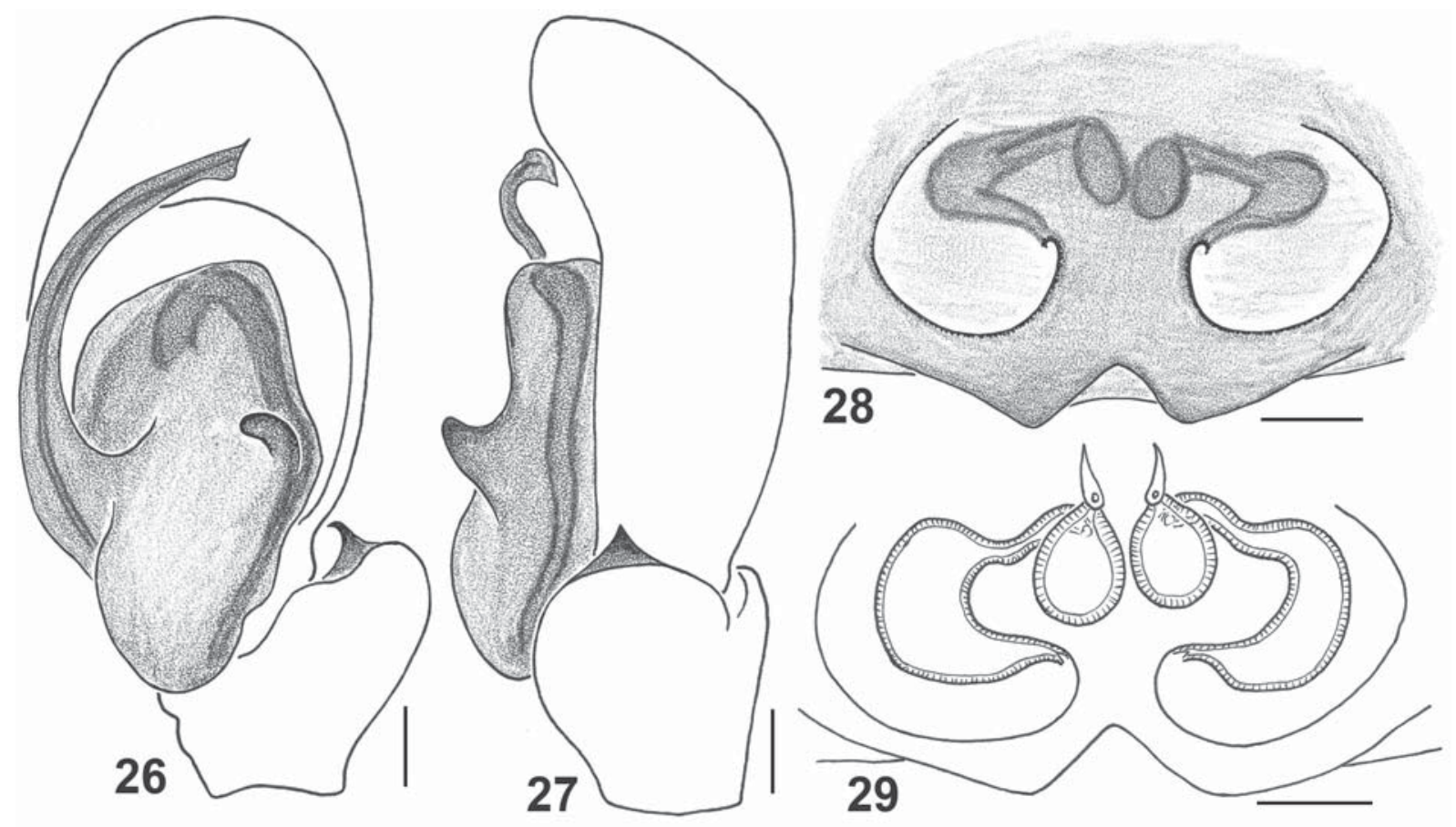

Figs 26-29. Epocilla aura (Dyal, 1935) comb.n., copulatory organs of the topotypes from Lahore, Pakistan: 26 - left palp, ventral view; 27 - ditto, retrolateral view; 28 - epigyne, ventral view; 29 - spermathecae, dorsal view. Scale bars: 0.1 mm. Images kindly provided by D.V. Logunov.

Рис. 26-29. Epocilla aura (Dyal, 1935) comb.n., копулятивные органы топотипов из Лахора, Пакистан: 26 - левая пальпа, вид снизу; 27 - то же, вид сбоку-сзади; 28 - эпигина вид снизу; 29 - сперматека, вид сверху. Масштаб: 0,1 мм. Изображения любезно предосталены Д.В. Логуновым.

between embolus and tegulum (Figs 15, 17, 26); see also Ali et al. [2018: sub E. pakhtunkhwa]. The female can be distinguished by the broader, longer insemination ducts and relatively smaller spermathecae which are situated closer to the epigastric furrow (Figs 8-9, 28, 29).

DESCRIPTION. Male. See Ali et al. [2018: sub E. pakhtunkhwa] for a detailed description.

Female (holotype of M. tigrina, Figs 7-11). Total length: 7.80; carapace: 3.01 long, 2.28 wide; abdomen: 4.79 long, 2.38 wide. Carapace reddish brown, covered with pale hairs; eye field light brown; posterior eyes surrounded by black patches; lateral margins of carapace with broad white patches (Fig. 7). Eye measurements: AME 0.48, ALE 0.21, PME 0.06 , PLE 0.22, AER 1.61, PER 1.58, EFL 0.99. Sternum oval, yellowish. Chelicerae yellow-brown, unidentate; labium and maxillae light brown. Legs yellowish brown (Fig. 7). Abdomen yellowish, with reddish-brown patches arranged dorsally with median chevron shaped pattern (Figs 7, 10); venter yellowish uniformly. Spinnerets yellowish. Epigyne with a pair of oval fossae; posterior margin wide w-shaped (Figs 8,11); copulatory openings lie at the medial region; insemination ducts broad and move anteriorly to the medially placed pear-shaped spermathecae (Fig. 9).

LIVE COLORATION. Male (Nashik, Maharashtra). Carapace reddish brown, with a reddish-brown hairs in the ocular region and a patch of white hairs in the middle, another longitudinal white patch seen behind the fovea; lateral margins with broad white patch and brown rim (Fig. 1). Clypeus blackish; anterior eyes surrounded by white orbital setae; chelicerae black; palps yellow covered with some white scales except brownish cymbium (Fig. 2). Leg I brown, with white scales except yellow metatarsi and tarsi; legs II-IV yellow (Figs 1-3). Abdomen reddish brown, with a pair of yellowish white lateral bands (Figs 1, 3). Female (Nashik, Maharashtra). Carapace yellowish, covered with white hairs and orange-red hairs along the eye region forming longitudinal pair of patches (Fig. 4). Clypeus covered with white hairs continuous with lateral broad white bands; anterior eyes surrounded with white orbital setae; palps, chelicerae and legs yellow (Figs 5, 6). Abdomen covered white hairs and reddish brown pattern forming chevrons in the middle (Fig. 4).

REMARKS. Dyal [1935] described 15 new salticid species from Lahore (Pakistan), of which, only seven have accompanying illustrations of the copulatory organs but none of these species have been either reported or redescribed later on, as the original descriptions are outdated and the illustrations not detailed enough to provide diagnostic characters supporting a precise identification. The matter is further complicated by the unavailability of type material of which whereabouts remains unknown. Therefore, the validity of the species described by Dyal could not been verified by contemporary workers, with some species names being presently considered nomen dubium or species inquirenda [Logunov, 2020; Sankaran et al., 2020; WSC, 2021]. There is a possibility that the material studied by Dyal might be kept in the department where he used to work as a Demonstrator in Zoology (Government College, Lahore), or could have been moved to the Stephenson Natural History Museum (https://gcu.edu.pk/zoology/).

While examining the type series of Marpissa tigrina kept in NZC, ZSIK along with newly collected specimens of 


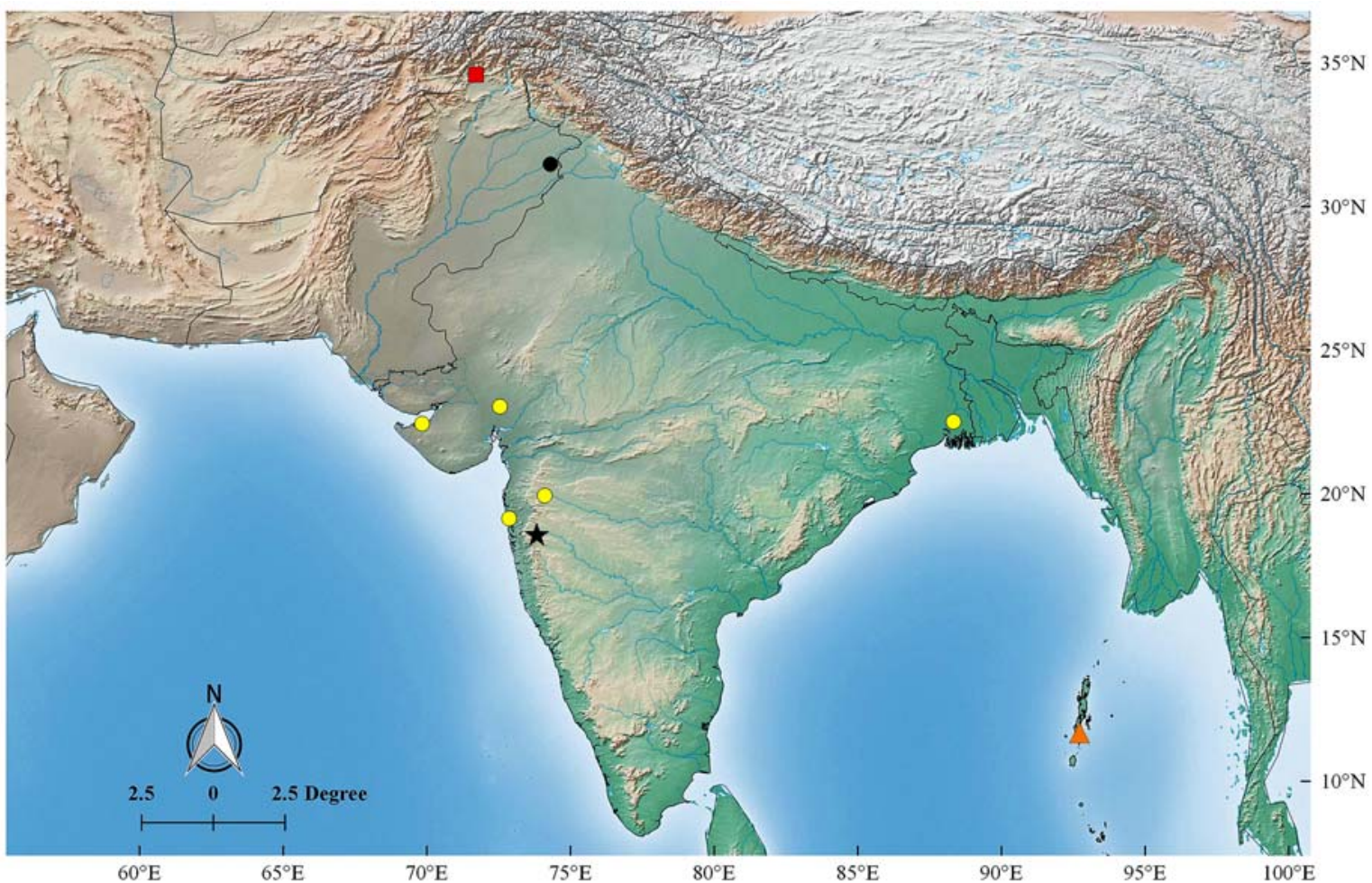

Map. Collecting localities of the studied Epocilla species: E. aura (Dyal, 1935) (yellow circles), with its type locality indicated with a black circle; black star, orange triangle and red square show the type localities of Marpissa tigrina Tikader, 1965, Marpissa kalapani Tikader, 1977 and Epocilla pakhtunkhwa Ali et Maddison, 2018 respectively.

Карта. Тоски находок изученных видов Epocilla: E. aura (Dyal, 1935) (желтые кружки), с типовым локалитетом, помеченным чёрным кружком; чёрная звезда, оранжевый треугольник и красный квадрат показывают типовые локалитеты Marpissa tigrina Tikader, 1965, Marpissa kalapani Tikader, 1977 и Epocilla pakhtunkhwa Ali et Maddison, 2018 соответственно.

both sexes from Maharashtra and Gujarat States of India and topotypes from Pakistan (see above, under 'Other Material'), we have been able to find the unknown male of this species. The species was originally misplaced in Marpissa C.L. Koch but is actually a member of Epocilla. The discovered male is identical in general morphology and the conformation of the copulatory organs to the recently described male of E. pakhtunkhwa from Pakistan: viz., dark brown clypeus; leg I robust with four pairs of ventral spines; embolus long and broad with an expanded flange at its tip; narrow, deep cleft between embolus and tegulum; swollen palpal tibia with two apophyses; RTA dark and curved towards the median axis (cf. Figs 13-21, 26, 27 with figs 1-4 in Ali et al. [2018]). The thickness of the embolus in all studied specimens varies.

Additionally, we have consulted the illustrations from Dyal [1935] and found out that the epigyne of Thiania aura (=Epocilla aura comb.n.) perfectly matches that of M. tigrina. Upon a detailed comparison of freshly collected topotypes of this species from Pakistan (Lahore) and those from India with the original description of $E$. aura, it has become evident that we are dealing with the same species. The following technical descriptions of the female and male taken from Dyal [1935: 230, 231] are in full agreement with those of the species illustrated here (cf. Figs 1-14, 18-25):

Female - "Carapace is yellowish, and has a pair of reddish brown bands between A.L. and base; cephalic region is darker, and bears long black hair; region of anterior row of eyes is brick red. Legs are greenish, except the tarsal joints which are brownish... Vulval aperture is bounded by two C-shaped plates whose anterior horns are joined to each other. The dorsum is golden yellow in colour and has a pair of reddish brown bands meeting posteriorly at the spinnerets; between the bands is a row of patches of brick red colour."

Male - "Cephalic region is lighter in color than in female; clypeus is black;... First pair of legs is heavy and reddish brown in colour, remaining legs are greenish but lighter than in female. Dorsum is ornamented as in the female except that the brick red patches are absent but is provided with hair of the same colour. A brick red line extends forwards to the margin of corselet."

Moreover, the illustration of the epigyne of $E$. aura added to the above description proved to be most useful in recognising this species. The conformation of the epigyne with a pair of oval fossae; the posterior margin of epigyne with a notch in the middle; a pair of the spermathecae partially seen through the integument depicted at the medial region are identical to those of $M$. tigrina (cf. Figs 8, 11 with fig. 177 in Dyal, 1935). Based on these observations, hence it is safe to conclude that both names - E. pakhtunkhwa and $M$. tigrina - are to be considered junior synonyms of $E$. aura.

DISTRIBUTION. Pakistan (Map), India (Gujarat, Maharashtra and West Bengal) (Map).

Epocilla calcarata (Karsch, 1880) Figs 30-35, Map.

Plexippus calcaratus Karsch, 1880: 398 (D० $\left.{ }^{7}\right)$. 

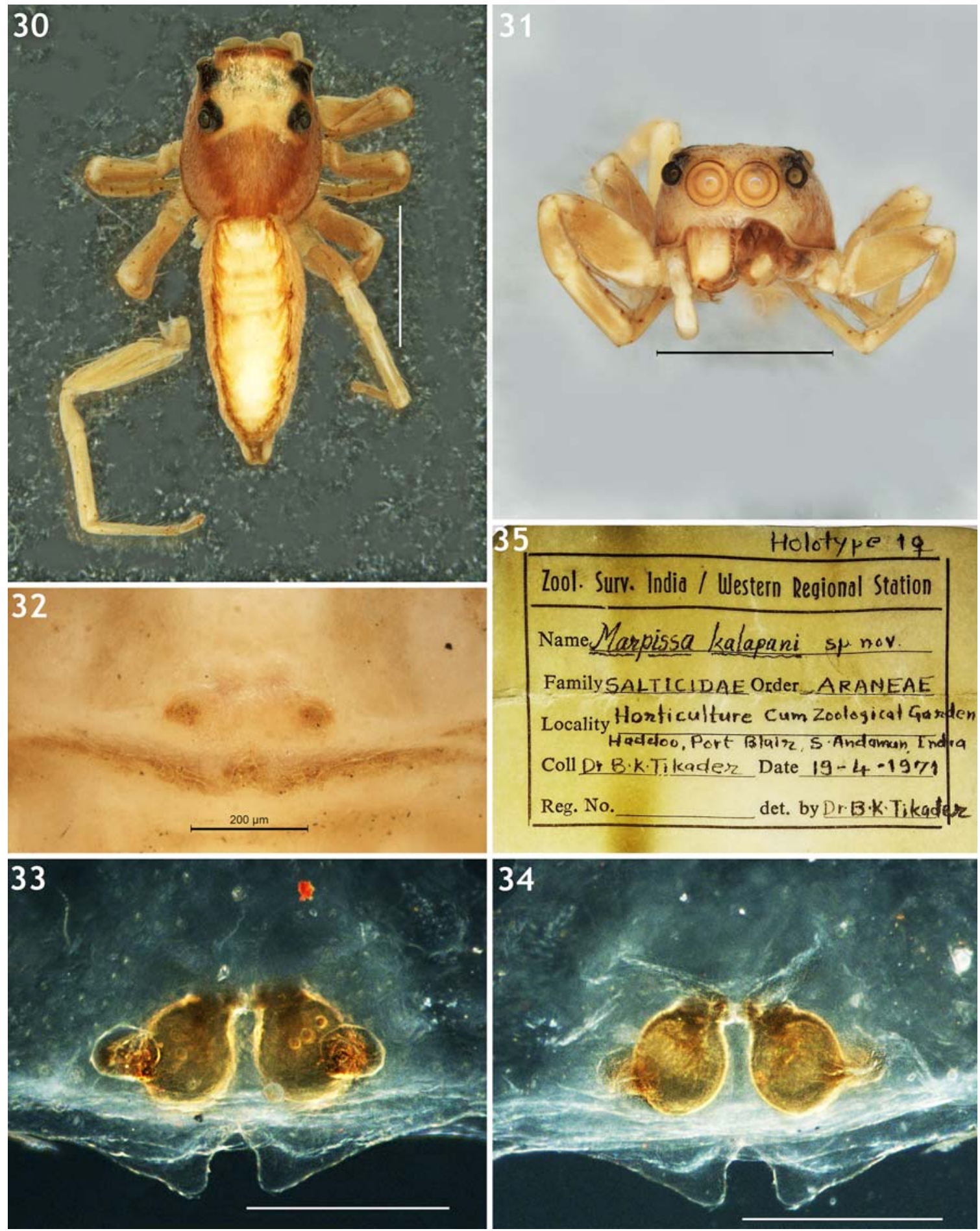

Figs 30-35. Epocilla calcarata (Karsch, 1880) (= Marpissa kalapani Tikader, 1977, syn.n.), the holotype female of M. kalapani: 30 body, dorsal view; 31 - front view; 32 - epigyne, ventral view; 33 - epigyne cleared, ventral view; 34 - spermathecae, dorsal view; 35 type data label. Scale bars: $(30,31) 2 \mathrm{~mm}$; (32-34) $0.2 \mathrm{~mm}$.

Рис. 30-35. Epocilla calcarata (Karsch, 1880) (= Marpissa kalapani Tikader, 1977, syn.n.), самка-голотип M. kalapani: 30 — тело, вид сверху; 31 - вид спереди; 32 - эпигина, вид снизу; 33 - осветленная эпигина, вид снизу; 34 - сперматека, вид сверху; 35 этикетка типа. Масштаб: (30, 31) 2 мм; (32-34) 0,2 мм.

Epocilla rufa Wesołowska, 1981: 52, figs 22-31 (D $\left.{ }^{7}+\right)$. Epocilla calcarata: Żabka, 1985: 217, figs 132-148.

Marpissa kalapani Tikader, 1977: 200, figs 23A-B (Dㅇ); holotype + in ZSIK, examined, syn.n.
For a complete list of taxonomic references refer the WSC [2021].

TYPE. Marpissa kalapani Tikader, 1977: HоLотуPE o (without registration number) from India, South Andaman, Port Blair, 
Haddoo $\left(11^{\circ} 40^{\prime} 38.6^{\prime \prime} \mathrm{N}, 92^{\circ} 43^{\prime} 26.0^{\prime \prime} \mathrm{E}\right)$, Horticulture cum Zoological garden, $61 \mathrm{~m}$ a.s.1., 19.04.1971, B.K. Tikader.

REMARKS. This species was described based on a single holotype female from the South Andaman Island [Tikader, 1977]. Prószyński [2016] provisionally argued to transfer the species to Epocilla reasoning from its colour pattern and epigyne conformation, but the transfer has not been formally done. Upon re-examination of the holotype, we have found out that the central cleft on the posterior margin of the epigyne, oval copulatory openings, short and straight insemination ducts and spherical spermathecae are identical to those of E. calcarata (cf. Figs 32-34 with figs 30-31 in Wesołowska [1981] and figs 146-148 in Żabka [1985]), and thus the name $M$. kalapani is to be considered a junior synonym of E. calcarata.

Acknowledgements. We are grateful to the Director of the Zoological Survey of India, Kolkata for allowing us to re-examine the types. Our sincere thanks go to the Officerin-Charge of the Division of Arachnology (ZSI, Kolkata) for the kind support and to Mr Chandan Bera for his curatorial assistance. Thanks go to Dr Krushnamegh Kunte, Lab 8, National Centre for Biological Sciences (NCBS), for his generous support. Finally, our sincere thanks go to Dr Dmitri Logunov (Manchester, UK) for generously providing additional information, images, drawings and distributional data of E. aura from Pakistan. We also wish to thank him for the positive comments/suggestions that helped us to improve the ms.

Compliance with ethical standards

Conflict of interest: The authors declare that they have no conflict of interest.

Ethical approval: No ethical issues were raised during our research.

\section{References}

Ali P.A., Maddison W.P., Zahid M., Butt A. 2018. New chrysilline and aelurilline jumping spiders from Pakistan (Araneae, Salticidae) // ZooKeys. Vol.783. P.1-15.

Caleb J.T.D., Sankaran P.M. 2021. Araneae of India. Version 2021, online at http://www.indianspiders.in [accessed on 21 January 2021]

Caleb J.T.D., Prajapati D.A., Rameshwar Maheshwari N., Sanap R.V. 2017. Redescription and synonymy of Stenaelurillus aram- bagensis (Biswas et Biswas, 1992) comb. n. (Araneae: Salticidae) // Arthropoda Selecta. Vol.26. No.2. P.119-123.

Caleb J.T.D., Prajapati D.A., Ali P.A. 2019. Redescription of Rudakius ludhianaensis (Tikader, 1974) (Aranei: Salticidae), with notes on its synonymy and distribution // Arthropoda Selecta. Vol.28. No.3. P.417-423.

Caleb J.T.D., Bera C., Acharya S. 2020. New species and synonymies in the genus Carrhotus Thorell, 1891 from India (Aranei: Salticidae: Salticini) // Arthropoda Selecta. Vol.29. No.1. P.5166.

Dyal S. 1935. Fauna of Lahore. 4.-Spiders of Lahore // Bulletin of the Department of Zoology of the Panjab University, Vol.1. P.119-252.

Karsch F. 1880. Arachnologische Blätter (Decas I) // Zeitschrift für die Gesammten Naturwissenschaften, Dritte Folge. Vol.5. P.373-409.

Logunov D.V. 2020. New and poorly known leaf-litter dwelling jumping spiders from South-East Asia (Araneae: Salticidae: Euophryini and Tisanibini) // Arachnology. Vol.18. No.6. P.521-562.

Prószyński J. 2016. Salticidae (Araneae) of the World, Chapter II; online at: http:/ http://www.salticidae.pl/ (accessed on 21 January 2021).

Sankaran P.M., Caleb J.T.D., Sebastian P.A. 2021. Revision of Indian wolf spiders: I. Genus Arctosa C.L. Koch, 1847 (Araneae: Lycosidae, Tricassinae) // Zootaxa. Vol.4908. No.4. P.489504.

Thorell T. 1887. Viaggio di L. Fea in Birmania e regioni vicine. II. Primo saggio sui ragni birmani // Annali del Museo Civico di Storia Naturale di Genova. Vol.25. P.5-417.

Tikader B.K. 1965. A new species of spider of genus Marpissa (Salticidae) from India // Science and Culture. Vol.31. P.261262.

Tikader B.K. 1977. Studies on spider fauna of Andaman and Nicobar islands, Indian Ocean // Records of the Zoological Survey of India. Vol.72. P.153-212.

Tikader B.K., Biswas, B. 1981. Spider fauna of Calcutta and vicinity: Part-I // Records of the Zoological Survey of India, Occasional Paper. Vol.30. P.1-149.

Wesołowska W. 1981. Salticidae (Aranei) from North Korea, China and Mongolia // Annales Zoologici, Warszawa. Vol.36. P.45-83.

WSC 2021. World Spider Catalog. Natural History Museum Bern; online at: http://wsc.nmbe.ch, version 22, (accessed on 21 January 2021).

Żabka M. 1985. Systematic and zoogeographic study on the family Salticidae (Araneae) from Viet-Nam // Annales Zoologici, Warszawa. Vol.39. P.197-485.

Responsible editor D.V. Logunov 